\title{
EQUILIBRIUM-LINE ALTITUDES AND PALEOENVIRONMENT IN THE MERCHANTS BAY AREA, BAFFIN ISLAND, N.W.T., CANADA
}

\author{
By FRED F. HAWKINS*
}

(Department of Geological Sciences and Institute of Arctic and Alpine Research, University of Colorado, Boulder, Colorado 80309, U.S.A.)

ABSTRACT. The fiordlands south of Merchants Bay contain an extensive, well-preserved moraine record of a late Foxe advance of local valley glaciers. This has allowed accurate reconstruction of former glacier margins and computation of former equilibrium-line altitudes (ELAs) by a variety of methods. Statistical comparison of three methods (maximum lateral-moraine elevation, median elevation, and accumulation area ratio (AAR)) shows that different techniques can give different results for the same glaciers. Lateral moraines gave estimates that were too low, probably due to post-glacial erosion or to non-deposition. Median elevations and the AAR method produced statistically similar results but only for glaciers of simple geometry. The median-elevation method fails to take into account variations in valley morphology and glaciological parameters, and so is not reliable in all situations. The AAR method is supported by empirical evidence and is the best of the three methods for estimating former ELAs.

Analysis of trend surfaces of present and late Foxe ELAs shows changes in elevation and orientation through time due to changing environmental factors. Present ELAs are strongly influenced by local factors, southerly storm tracks, and warm maritime conditions. Paleo-ELAs do not show this influence, suggesting that Davis Strait may have been ice-covered during the late Foxe stade and that storm tracks were from the north.

Résumé. Altitudes de la ligne d'équilibre et paléoenvironnement dans la Baie des Marchands, Ile de Baffin, N.W.T. Canada. Les fiords au sud de la Baie des Marchands présentent une longue moraine bien préservée qui témoigne de la dernière avancée du Foxe pour les glaciers de vallée du lieu. Ceci a permis une reconstitution précise des anciennes limites des glaciers et un calcul des altitudes de la ligne d'équilibre (ELAs) par différentes méthodes. Une comparaison statistique des trois méthodes (hauteur maximale des moraines latérales, altitude moyenne, et proportion de la surface d'accumulation (AAR)) montre que des techniques différentes conduisent à des résultats différents pour les mêmes glaciers. Les moraines latérales ont donné des estimations trop basses, probablement dues à l'érosion post-glaciaire ou au manque de dépôt. Les altitudes moyennes et la méthode de l'AAR donnent des altitudes statistiquement semblables pour des glaciers de géométrie simple. L'altitude moyenne ne prend pas en compte les changements de morphologie de la vallée ni les paramètres glaciologiques et pour cela elle n'est pas fiable dans toutes

\section{INTRODUCTION}

That there is an important relationship between glacier mass balance and environment has been recognized for nearly a century (Østrem, 1966), yet a great deal of

Present address: U.S. Bureau of Reclamation, D-1632, Bóx 25007, Denver Federal Center, Denver, Colorado 80225 , U.S.A. les situations. La méthode de l'AAR est confirmée par des preuves empiriques et elle est la meilleure des trois méthodes pour estimer les ELAs passées.

Des analyses des tendances de surface entre les ELAs présentes et du Foxe montrent des changements en altitude et orientation dans le temps dus aux variations des facteurs d'environnement. Les ELAs actuelles sont fortement influencées par des facteurs locaux, les trajets des précipitations du Sud, et les conditions maritimes tempérées. Les Paléo-ELAs ne révèlent pas cette influence, ce qui suggère que le détroit de Davis a pu être couvert de glace pendant le stade de Foxe et qu'alors les trajets des précipitations ont pu venir du Nord.

ZUSAMMENFASSUNG. Höhen der Gleichgewichtslinie und frühere Umweltbedingungen im Gebiet der Merchants Bay, Baffin Island, N.W.T., Kanada. Die Fjordküsten südlich der Merchants Bay vermitteln einen ausgedehnten, gut erhaltenedn Nachweis von Moränen eines späten Foxe-Vorstosses lokaler Talgletscher. Dies ermöglichte eine genaue Rekonstruktion früherer Gletscherstände und eine Berechnung der Höhen früherer Gleichgewichtslinien (ELA) mit mehreren Methoden. Der statistische Vergleich von drei Methoden (maximale Höhe der Seitenmoräne, mittlere Höhe, relativer Flăchenanteil des Akkumulationsgebietes (AAR)) zeigt, dass verschiedenes Vorgehen zu verschiedenen Ergebnissen für dieselben Gletscher führen kann. Seitenmoränen ergeben zu niedrige Abschätzungen, vermutlich infolge postglazialer Erosion oder wegen fehlender Ablagerung. Mittlere Höhen und die AAR-Methode lieferten statistisch ähnliche Ergebnisse, jedoch für Gletscher mit einfacher Geometrie. Die Methode der mittleren Höhe ist nicht in der Lage, Änderungen in 'er Talgestalt und bei glaziologischen Parametern zu berücksichtigen, weshalb sie nicht in allen Făllen zuverlăssig ist. Die AAR-Methode wird durch Erfahrungswerte gestützt und ist deshalb das beste von den drei Verfahren zur Abschătzung früherer Höhen der Gleichgewichtslinie.

Die Analyse tendenzieller Oberflächen gegenwărtiger und später Foxe-Stadien zeigt zeitliche Änderungen in Höhe und Orientierung infolge wechselnder Umweltverhältnisse. Gegenwärtige Höhen der Gleichgewichtslinie sind stark durch lokale Verhältnisse, Sturmbahnen aus dem Süden und warme maritime Bedingungen beeinflusst. Ältere Höhen zeigen diesen Einfluss nicht; dies führt zu der Annahme, dass die Davis Strait im späten Foxe-Stadium eisbedeckt war und die Sturmbahnen vom Norden Kamen.

uncertainty and confusion still exists regarding definitions and usage of the numerous mass-budget terms, methods of determining mass balance and equilibrium-line altitudes (ELAs), and the exact nature of the interplay of factors that link glaciers, climate, and environment. Different methods of determining ELAs have been employed by various workers in the past.

The first objective of this paper is to compare statistically three common methods of determining former equilibrium-line altitudes (paleo-ELAs). These methods are: 
(1) Determination of the former glacier's median elevation.

(2) Determination of the maximum elevation of the lateral moraine.

(3) Determination of the altitude at which the ratio of accumulation area to total glacier area is 0.65 .

A second objective is to calculate paleo-ELAs of a sample of reconstructed glaciers in eastern Baffin Island, and to analyze the regional trend of paleo-ELAs. Thirdly, regional trends of present and paleo-ELAs are compared in an attempt to infer paleoenvironmental conditions during the last glaciation (Foxe glaciation).

\section{THE STUDY AREA}

Merchants Bay is located on the north-east coast of Cumberland Peninsula, roughly midway between Broughton Island and Cape Dyer, and adjacent to Padloping Island (Fig. 1a). Field work was conducted in 1978 in the fiordland south of Merchants Bay. The study area encompasses the watersheds of two large fiords, known locally as Kangetokjuak (big fiord) and Kangetogusikruluk (big, bad fiord), an area of roughly $3500 \mathrm{~km}^{2}$.

The area is characterized physiographically by a fiord coastline incised into glacierized, fretted mountains with summits 1400-1700 m a.s.1. Broad, deep glacial valleys extend from cirques along the range crests to the present shoreline. Outlet glaciers of small intermontane ice fields are the largest glaciers in the area; they terminate 100-300 m a.s.l. Cirque glaciers and small, independent valley-glacier systems are more numerous; these terminate between 300 and $600 \mathrm{~m}$ a.s.l.

The Merchants Bay area was chosen for this study for several reasons. Foremost among them is the wide distribution and excellent preservation of a large suite of late Foxe moraines (Miller, unpublished). At least 34 glaciers extended beyond their present or Neoglacial boundaries and produced moraine systems and other geomorphic features continuous enough to allow accurate reconstruction of former glacier outlines on air photographs. The photogrammetric technique employed in surficial geologic mapping of the study area (Hawkins, unpublished) permitted precise compilation of former glacier margins, including the highest points on lateral moraines, on a base map. This in turn facilitated the statistical comparison described below.

\section{DEFINITION OF TERMS}

The collection of glacier mass-balance terms has not grown in any systematic manner. Although many of the terms have been in general use for nearly a century, efforts to standardize definitions and usage have been limited and ambiguity commonly results.

An admirable attempt to define mass-balance terms systematically was that of Meier (1962). Other definitions that might be adopted as future standards are contained in Bates and Jackson (1980). The definitions cited below are drawn largely from these sources.

The term "snowline" is so vague that its use, without an appropriate modifier, is not recommended for any but the most general applications. "Equilibrium line" is a much more precise term, and will be used henceforth. It is defined as the "line" on a glacier that divides the area of net accumulation from the area of net ablation at the end of the ablation season in any year. "Firn line" and "climatic snowline" are of ten used as synonyms for "equilibrium line", usually erroneously. The firn line coincides with the equilibrium line only in the case of temperate mountain glaciers (Meier, 1962); "climatic snowline" has multiple meanings and is of limited operational usefulness.

Clearly, the equilibrium-line altitude (ELA) will vary in response to changing climatic effects from year to year (Dugdale, 1972), and over longer periods. However, if a glacier experiences an interval of relatively stable climate, the ELA will remain essentially constant, as will the
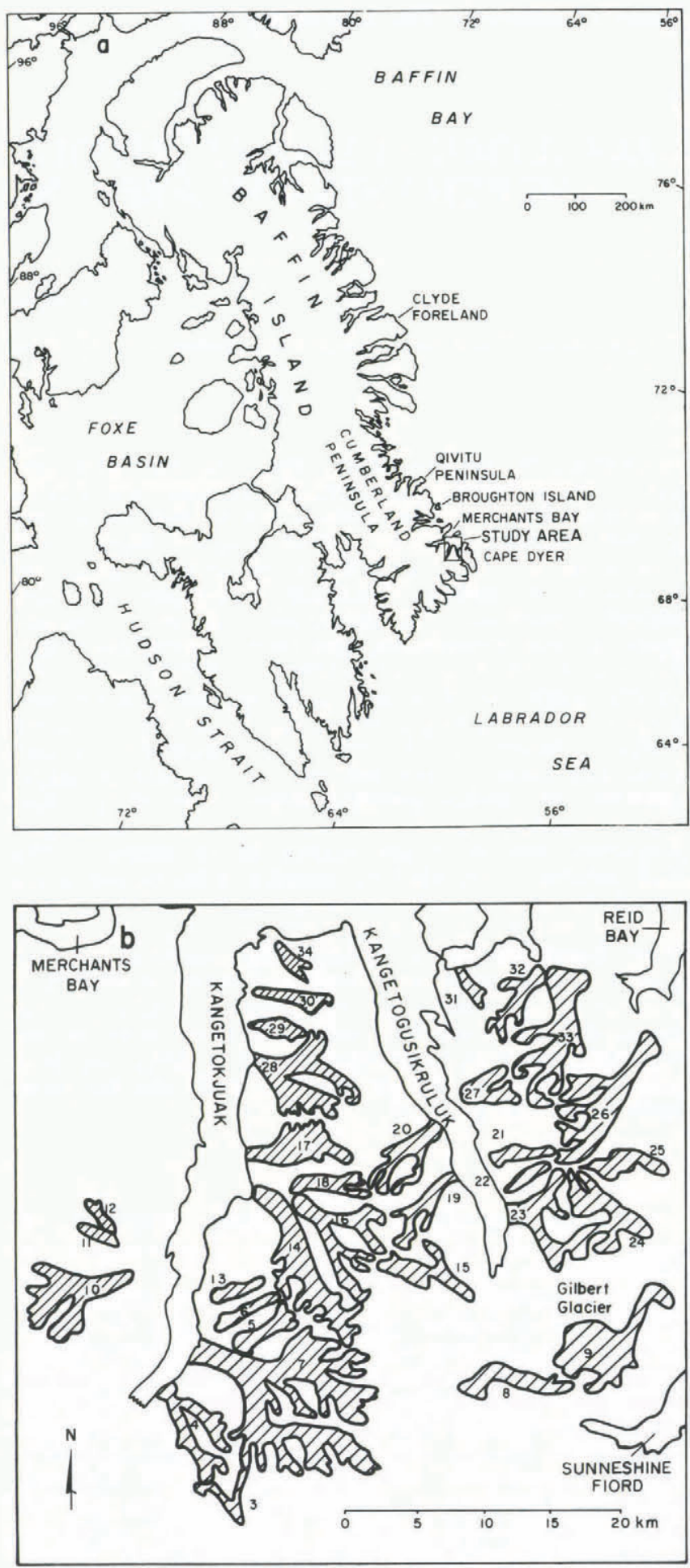

Fig. 1. a. Index map of Baffin Island showing the location of the study area.

b. Map of reconstructed late Foxe glaciers (cross-hatched). Numbers correspond to glacier numbers in Table I.

position of the glacier margin. The ELA of a glacier in long-term equilibrium $\left(10^{2}-10^{4}\right.$ years) is then called the "steady-state ELA"; it is this parameter that we wish to calculate in order to make regional comparisons and paleoenvironmental interpretations.

If steady-state ELAs are computed for a substantial number of glaciers in one area, then one can determine the "regional trend of ELAs". This is essentially what is referred to as the "regional snowline", a name that is misleading as it describes a surface rather than a line. 


\section{METHODS OF DETERMINING PALEO-ELAS}

ELAs can be estimated in a number of ways. The papers by Østrem (1966), Flint $\left(\left[{ }^{\mathrm{c}} 1971\right]\right)$, and Andrews ([ $\left.\left.{ }^{\mathrm{C}} 1975\right]\right)$ contain descriptions of various methods commonly employed. Two techniques that have gained wide attention are analysis of cirque-floor elevations (Porter, 1964; Andrews, 1965; Peterson and Robinson, 1969; Meierding, 1982; Williams, 1983; Williams, unpublished) and determination of the glaciation limit (Østrem, 1966; Andrews and Miller, 1972; Pierce, 1979; Meierding, 1982).

It has been noted by previous workers (Porter, 1964; Williams, unpublished) that cirque-floor elevations indicate a "composite snowline" for all cirque glaciations that have occurred in an area, although what sort of snowline they represent is less clear. Williams (unpublished, p. 33-35) observed that cirque floors lie $150-750 \mathrm{~m}$ below cirque-glacier ELAs, and that their elevations can be controlled by the vertical extent of valley glaciers. Furthermore, little information concerning valley-glacier ELAs can be obtained from cirque-floor elevations. Finally, while trend-surface analysis improves the utility of cirque-floor elevations in estimating a "regional snowline" (Peterson and Robinson, 1969), the factor of elevational control by valley glaciers is still a serious limitation (Williams, unpublished).

The glaciation limit, in contrast to cirque-floor elevations, generally lies above the ELAs of mountain glaciers (Østrem, 1966; Andrews and Miller, 1972); the average difference for Baffin Island is about $200 \mathrm{~m}$. Although the glaciation limit is a valuable and easily determined parameter in currently glacierized regions, it is more difficult to estimate for past glacial ages (Andrews, [ $\left.{ }^{\mathrm{C}} 1975\right]$ ).

\section{Glacier reconstructions}

In this study, three methods of estimating steady-state ELAs of former glaciers are compared to see whether they yield statistically similar results. All three methods require some form of glacier reconstruction.

Thirty-four late Foxe glacier outlines were reconstructed on air photographs using morphostratigraphic data. The method used was similar to that employed by Sissons and Sutherland (1976) for former glaciers in Scotland. Terminal and lateral moraines, areas of glacial scour, vegetation trimlines, and present ice extent in cirques were used to define former glacier margins on air photographs. For glaciers that formerly extended beyond the modern shoreline, the ice terminus was inferred using the outlines of outwash deltas, which can be delineated on air photographs where these deltas exist. Glacier plans were compiled photogrammetrically on a $1: 62500$ enlargement of the Cape Dyer 1:250000 topographic base map, and ice-surface contours were inferred. Figure $1 \mathrm{~b}$ shows reconstructed glacier outlines.

\section{Median elevation}

Since the late nineteenth century in Europe, the median elevations of former glaciers have been used to estimate ELAs (Manley, 1959; Østrem, 1966). The same technique has been employed by Richmond (1965) and Meierding (1982) in the United States. There is no apparent indication in the English-language literature why this value should approximate the ELA. Indeed, empirical evidence from modern glaciers suggests that it should be too high (Meier and Post, 1962). Furthermore, the technique fails to take into account variations in valley morphology, which would affect the area-elevation distribution of a glacier. To this end, Manley (1959) suggested that, for glaciers whose valleys narrow markedly in their lower reaches, the ELA is three-fifths of the vertical distance up the glacier from the terminal moraine. Finally, the term "backwall elevation", which can have a variety of meanings from the outset, becomes difficult to define for valley glaciers that head in compound cirques. For this reason, the method was applied in this study only to glaciers of simple geometry. For these ice masses it was deemed unnecessary to apply Manley's three-fifths method.

Constraints on the accuracy of median-elevation estimates are imposed by reliability of the base map, which in this case has a contour interval of $500 \mathrm{ft}$ [approximately $150 \mathrm{~m}$ ], lacks geodetic control, and was unchecked in the field. Elevations of terminal moraines and cirque backwalls that lie between contours were estimated by linear interpolation. Backwall elevations were taken as the base of the wall or, in the case of glacierized cirques, the elevation of the bergschrund (Manley, 1959; Andrews, 1965).

\section{Maximum elevation of lateral moraines}

Because of the nature of glacier flow, lateral moraines theoretically should be deposited solely in the ablation zone, that is, at or below the ELA (Andrews, [ $\left.{ }^{c} 1975\right]$ ). Therefore, the maximum elevation of the lateral moraines would approximate the ELA. However, it is often difficult to determine, even with extensive field work, whether or not the landform is preserved entirely in its upper reaches. Lack of physical preservation becomes more problematical as age of the landform increases. ELA estimates derived from eroded lateral moraines would be too low. Similarly, non-deposition would cause low estimates. Conversely, the assumption that the maximum height of a lateral moraine is reached during steady-state conditions can lead to estimates of the steady-state ELA that are too high. If the initial phase of glacier retreat is slow, then additional morainal material could be added to the lateral moraine above the position of the former steady-state ELA. The same effect could be achieved if influx of debris from the valley wall in the accumulation zone were very rapid (i.e. more rapid than the glacier's rate of flow).

It was originally intended that late Foxe lateral-moraine elevations would be measured by altimeter survey in the field; however, several test traverses showed that barometric fluctuations in the field area in the course of a day were great enough to cancel any advantage in accuracy that might have been gained through use of this method. This was especially true when the time required for each traverse was considered. The alternative was to estimate lateral-moraine elevations from the morphostratigraphic map. Elevations thus determined, as with the previous method, are probably accurate to within $\pm 35 \mathrm{~m}$. However, there is no reason why errors introduced in this way should be biased toward one method or another, and they should average zero.

\section{Accumulation-area ratio}

A method of determining ELAs that is supported by a large amount of observational evidence involves calculation of the "accumulation-area ratio" (AAR) (Meier and Post, 1962). This is defined as the ratio of the accumulation area (area above the ELA) to the total glacier area. The AAR of a glacier varies as a function of its mass balance, with ratios below 0.50 indicating negative mass balances, AARs from 0.50 to 0.80 corresponding to steady-state conditions, and values greater than 0.80 occurring under strongly positive regimes. An AAR of $0.65 \pm 0.05$ is generally considered to be a characteristic value for steady-state conditions of valley glaciers (Porter, 1968, 1970, 1975; Andrews and Miller, 1972; Andrews, [c 1975$]$ ). Values for ice caps and piedmont glaciers may differ significantly (Meier and Post, 1962; Pierce, 1979).

Calculation of late Foxe AARs was effected using reconstructed glacier outlines. Increments of area between ice-surface contours were measured to the nearest hectare using a digitizing electronic planimeter. The total area was also measured. Increments of area were summed, expressed as percentages of total area, and plotted on cumulative curves (Fig. 2). The steady-state ELA was read directly from a cumulative curve, as the elevation above which $65 \%$ of the glacier's area lies. There are several possible sources of error in computing ELAs in this way. The error associated with lack of an accurate large-scale base map is not unique to this method but is inherent in each technique.

There is some uncertainty in the correctness of assuming an AAR of 0.65 , as this figure is dependent upon the skewness of glacier-area distribution about the median elevation and upon the nature of the change in net budget with altitude (Meier and Post, 1962). For reconstructed glaciers, it is a simple matter to estimate ELAs from the cumulative curves using different AARs and to analyze the 

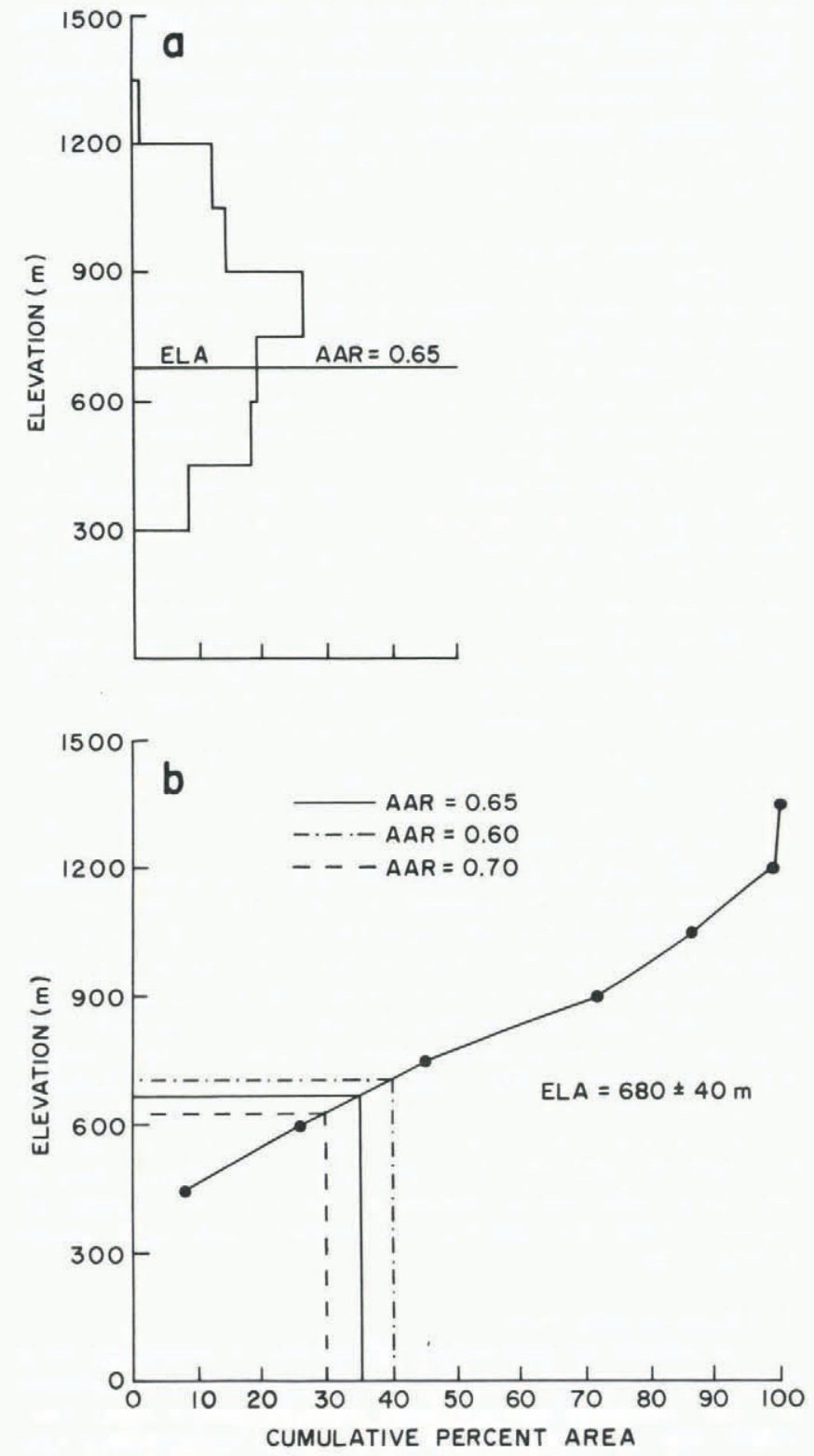

Fig. 2. Graphs of glacier area as a function of elevation. a. Area-elevation histogram of a reconstructed late Foxe glacier (glacier No. 25; Fig. 1b). b. Cumulative curve for the same glacier showing the graphical method used to determine steady-state ELAS.

magnitude of variation. The curves are steep enough in the affected part that for AARs of 0.60 and 0.70 the mean departure (from ELAs determined with an AAR of 0.65) is $\pm 35 \mathrm{~m}$, about $\pm 7 \%$. Choosing an AAR of 0.65 does not yield significantly different ELAs than those derived using AARs within the range of $0.60-0.70$.

The introduction of measurement errors was minimized through a series of checks on planimetry. For each glacier measured, the sum of incremental areas was compared with the total glacier area obtained by tracing the full glacier outline. A precision standard was arbitrarily set at $2 \%$ of total area; in most cases the difference was less than $1 \%$. Another test of precision involved ten replicate measurements of a single glacier of moderately complex shape. This yielded a mean of $9.80 \mathrm{~km}^{2}$, a standard deviation of $\pm 0.02 \mathrm{~km}^{2}$, and a coefficient of variation of $0.20 \%$. Precision of glacier-area measurements is clearly adequate.

The largest single source of inaccuracy related to the AAR method of determining paleo-ELAs is the reconstruction of ice-surface contours. Even when the glacier outline can be inferred with considerable confidence, it is sometimes difficult to locate contours. This is because glacier margins of ten intersect valley-side topographic contours at small angles or coincide with them for some distance. The effect on inferred area-elevation curves can be significant and considerably different ELA values can result. Unfortunately, little more can be done than to note the existence of the problem. However, there is no reason why these errors should be biased toward any one part of the study area; spatially, the errors can be considered to be randomly distributed.

Statistical comparison of the results of these three methods was made using the $F$ statistic for analysis of variance, and a paired $t$ test for evaluating equality of means of ELAs. All tests were conducted at the $95 \%$ confidence level.

\section{METHOD OF DETERMINING PRESENT ELAS}

ELAs were determined for 42 existing glaciers chosen from about 500 in the study area. Glacier outlines and surface contours were taken directly from the enlarged (1: 62 500) base map. An AAR of 0.65 was assumed as before but this premise requires further qualification.

The glaciers in the Merchants Bay area are not in equilibrium at present; they are retreating. If ELAs were determined from observations of a single budget year, either directly in the field or from 1956 air photography, the value obtained would be an "instantaneous" ELA rather than an average one based upon a period of climatic significance. Therefore, ELAs were computed as though the present ice masses were in a steady state. Because glacier regimes under the present climate are negative, the calculated ELAs are lower than the actual current values and late Foxe ELA depression, discussed below, is a minimum estimate. Nevertheless, the estimates of present ELAs are higher than ELAs at the Neoglacial maximum, because the areas of Neoglacial ice-cored moraines were not included in the planimetric measurements.

\section{METHODS OF ELA MAPPING}

\section{Trend-surface analysis}

ELAs of present and late Foxe glaciers were mapped using trend-surface analysis. This method has seen widespread application in geologic research; general discussions of trend mapping can be found in Krumbein and Graybill (1965) and Davis (1973). In glaciological studies, the technique has been used by Peterson and Robinson (1969), Andrews and others (1970), Andrews and Miller (1972), Sissons and Sutherland (1976), Meierding (1982), and Williams (unpublished). L.D. Williams supplied the FORTRAN program used in this study. The advantage of trend-surface analysis is that it separates changes in a dependent variable (ELA), with respect to two independent variables (horizontal coordinates), into a regional component (regression) and a local component (residuals). Thus, comparison of maps of two or more data sets is simplified greatly as compared with manually produced contour maps. Another attractive feature of trend mapping is that regression equations of successively higher order can be fitted to the data, thereby allowing more or less of the local deviation to be included in the regional trend. Finally, trend surfaces can be analyzed by statistical methods.

For past and present Merchants Bay ELAs, first-, second-, and third-order equations were fitted to the data. The $F$ distribution was used to test the significance of the surfaces, that is, to answer the question "Is there a regional trend, or do ELAs vary randomly across the study area?" The $F$ test was also used to determine whether the addition of quadratic and cubic terms to the linear-trend equations significantly improved the amount of variance explained by the regression. If the explanation of variance was not substantially improved, it was deemed inappropriate to increase the order of the equation. All statistical hypotheses were tested at the $95 \%$ confidence level. Strength of trends (i.e. goodness-of-fit) is indicated by the per cent of total variance explained by the regression $\left(R^{2} \times 100\right)$ and by the coefficient of multiple correlation $(R)$.

Variation through time in the regional trend of 
TABLE I

ELA DATA FOR 34 LATE FOXE GLACIERS

$\begin{array}{rrrcc}\begin{array}{l}\text { Glacier } \\ \text { number* }\end{array} & \begin{array}{r}\text { Total } \\ \text { area }\end{array} & \text { AAR } & \begin{array}{c}\text { Lateral } \\ \text { moraine }\end{array} & \begin{array}{c}\text { Median } \\ \text { elevation }\end{array} \\ & & & & \mathrm{m} \\ & \mathrm{km}^{2} & \mathrm{~m} & \mathrm{~m} & \mathrm{~m} \\ 1 & & & & \\ 2 & 8.41 & 685 & 460 & - \\ 3 & 5.88 & 685 & 610 & - \\ 4 & 3.25 & 685 & 550 & - \\ 5 & 12.96 & 535 & 460 & - \\ 6 & 5.64 & 570 & 530 & 610 \\ 7 & 3.87 & 610 & 610 & 595 \\ 8 & 65.05 & 570 & 610 & - \\ 9 & 8.14 & 495 & 460 & 570 \\ 10 & 22.76 & 630 & - & - \\ 11 & 20.50 & 640 & 460 & - \\ 12 & 3.11 & 685 & 760 & 800 \\ 13 & 2.35 & 755 & 760 & - \\ 14 & 2.59 & 570 & 610 & 610 \\ 15 & 23.72 & 380 & 490 & - \\ 16 & 9.69 & 655 & 460 & 685 \\ 17 & 17.52 & 430 & 460 & - \\ 18 & 14.32 & 490 & 490 & - \\ 19 & 6.11 & 470 & 460 & 650 \\ 20 & 8.53 & 520 & 380 & - \\ 21 & 10.17 & 465 & 460 & - \\ 22 & 3.70 & 435 & 305 & 510 \\ 23 & 3.26 & 585 & 460 & 455 \\ 24 & 12.27 & 365 & 460 & - \\ 25 & 17.17 & 665 & 460 & - \\ 26 & 7.37 & 680 & 610 & - \\ 27 & 23.85 & 540 & 230 & - \\ 28 & 8.25 & 395 & 305 & 435 \\ 29 & 19.66 & 465 & 490 & - \\ 30 & 4.22 & 510 & 490 & 425 \\ 31 & 8.17 & 460 & 305 & 490 \\ 32 & 2.92 & 425 & 305 & 380 \\ 33 & 8.12 & 265 & 305 & - \\ 34 & 4.26 & 305 & 305 & - \\ & 4.01 & 505 & 530 & 455 \\ & & & & \end{array}$

* For locations of glaciers see Figure $1 \mathrm{~b}$.

\section{ELA DATA FOR PRESENT GLACIERS}

\begin{tabular}{|c|c|c|}
\hline $\begin{array}{l}\text { Glacier } \\
\text { number }\end{array}$ & $\begin{array}{l}\text { Total } \\
\text { area }\end{array}$ & $E L A$ \\
\hline & $\mathrm{km}^{2}$ & $\mathrm{~m}$ \\
\hline 1 & 0.94 & 775 \\
\hline 2 & 15.16 & 725 \\
\hline 3 & 6.71 & 520 \\
\hline 4 & 0.77 & 520 \\
\hline 5 & 1.06 & 640 \\
\hline 6 & 1.25 & 655 \\
\hline 7 & 4.64 & 455 \\
\hline 8 & 4.87 & 655 \\
\hline 9 & 0.67 & 950 \\
\hline 10 & 1.99 & 745 \\
\hline 11 & 2.20 & 580 \\
\hline 12 & 1.92 & 505 \\
\hline 13 & 0.54 & 580 \\
\hline 14 & 2.31 & 520 \\
\hline 15 & 1.65 & 715 \\
\hline 16 & 0.48 & 945 \\
\hline 17 & 3.06 & 650 \\
\hline 18 & 3.47 & 650 \\
\hline 19 & 0.94 & 1225 \\
\hline 20 & 1.43 & 1250 \\
\hline 21 & 1.82 & 730 \\
\hline 22 & 1.40 & 870 \\
\hline 23 & 2.54 & 710 \\
\hline 24 & 0.85 & 685 \\
\hline 25 & 0.68 & 770 \\
\hline 26 & 1.70 & 695 \\
\hline 27 & 0.46 & 650 \\
\hline 28 & 1.24 & 790 \\
\hline 29 & 0.43 & 775 \\
\hline 30 & 1.10 & 730 \\
\hline 31 & 1.20 & 740 \\
\hline 32 & 1.99 & 815 \\
\hline 33 & 5.46 & 610 \\
\hline 34 & 0.88 & 870 \\
\hline 35 & 0.45 & 975 \\
\hline 36 & 0.76 & 815 \\
\hline 37 & 7.67 & 790 \\
\hline 38 & 4.79 & 800 \\
\hline 39 & 1.84 & 875 \\
\hline 40 & 0.89 & 870 \\
\hline 41 & 1.66 & 930 \\
\hline 42 & 0.58 & 850 \\
\hline
\end{tabular}

Merchants Bay ELAs was analyzed by comparison of trend surfaces, as well as by comparison of present and paleo-ELAs of individual glaciers. Regional ELA depression was determined by using 95 grid points predicted by the regression equations. The differences were plotted on a map and contoured. ELA lowering was also computed by using raw data from 23 existing and late Foxe glaciers whose locations coincide.

\section{RESULTS}

Comparison of paleo-ELA estimates

Original paleo-ELA data used to perform the comparisons are given in Table I. The outcome of statistical comparisons of three methods of paleo-ELA calculation is summarized in Table II.

For AAR versus lateral-moraine elevation, the null hypothesis, $H_{0}: \mu_{1}=\mu_{2}$, can be rejected at the $99 \%$ confidence level. The mean difference $(z)$ is positive, with individual ELA differences as great as $300 \mathrm{~m}$. This suggests that paleo-ELA estimates based upon maximum elevations of lateral moraines are generally too low, which points to the importance of non-deposition or post-glacial erosion of lateral moraines.

Comparison of lateral-moraine elevations and median elevations also shows that the two means are unequal at the
99\% confidence level. Lateral moraines are mostly lower than median elevations by as much as $200 \mathrm{~m}$.

For 15 late Foxe glaciers of simple geometry, the mean of ELAs determined using the AAR method is equal to the mean of median elevations at the $95 \%$ confidence level. If large, complex valley glaciers had been included in the sample, the results no doubt would have been quite different, due to the effect of changes in the symmetry of areal distribution about the median elevation (Meier and Post, 1962). Furthermore, the median elevations used in the test were derived by the method of Manley (1959), who considered the "backwall elevation" to be the elevation at the base of the crags. In contrast, American workers (Richmond, 1965; Flint, 1971; Meierding, 1982) have taken the top of the cirque wall as the "backwall elevation", which would yield higher ELA estimates.

In conclusion, while lateral moraines are valuable as geomorphic evidence for fixing reasonable limits for former ice extent, they are unreliable indicators of former ELAs and their use could result in an overestimate of the magnitude of climatic change, as reflected by ELA lowering. Although this study shows that it is possible to have broad regional correlation between ELAs determined by the AAR and median-elevation methods, the use of the latter method is probably worthwhile only in a limited number of situations, because it does not take into account 


\section{TABLE II. STATISTICAL COMPARISON OF THREE METHODS OF PALEO-ELA RECONSTRUCTION}

$H_{\mathrm{O}}: \mu_{1}=\mu_{2} ; \mu=$ population mean of ELAs estimated by each method

$\alpha=0.05$

$t=\frac{\bar{z}}{s_{Z} / n} \quad$ where:

$\bar{z} \quad s_{z} \quad n \quad t_{\text {test }}{ }^{t}(0.05, v)$
A Elevation at which $\mathrm{AAR}=0.65$.
L Maximum lateral moraine elevation.
M Median elevation.

the variability of mass balance or areal distribution with respect to elevation. Its use is not recommended, therefore, and those who find it necessary to employ the method should be aware of its limitations. Finally, this study shows that direct comparison of ELAs that have been computed by various methods in different regions can lead to erroneous conclusions, and must be attempted with caution.

\section{Analysis of trend surfaces}

Linear-trend surfaces of present and paleo-ELAs are shown in Figures 3 and 4 , respectively. Statistical data pertaining to the trends are given in Table III.

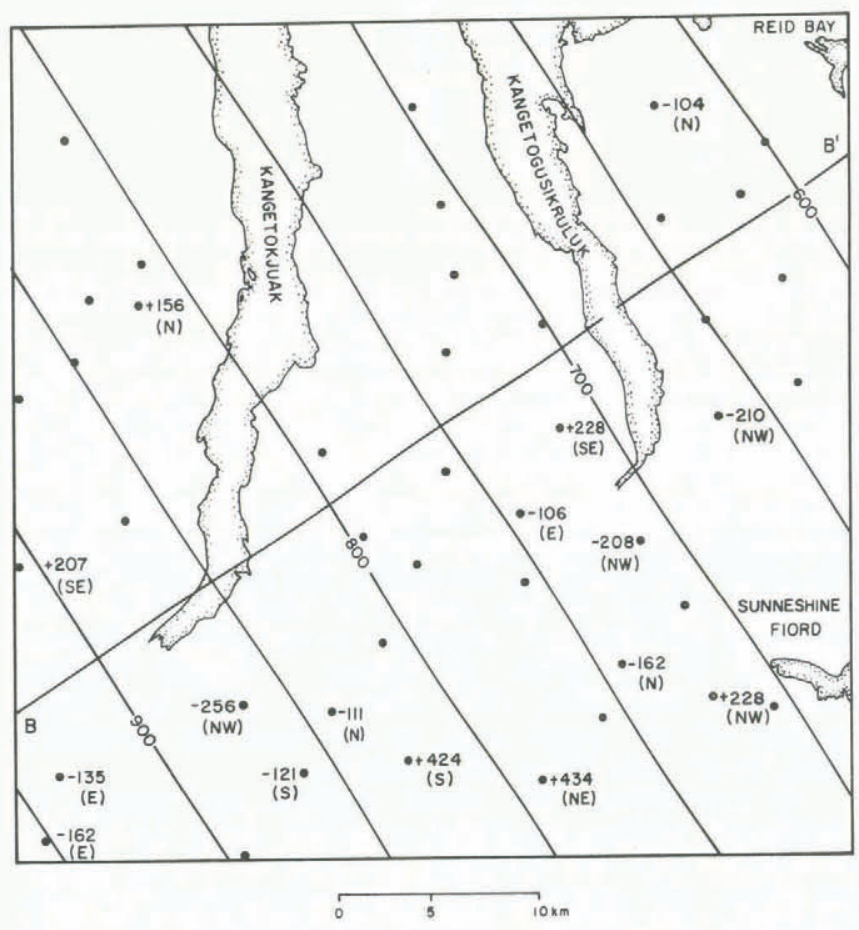

Fig. 3. First-order trend surface of present Merchants Bay ELAs showing the distribution of data points, residuals in excess of $\pm 100 \mathrm{~m}$, and general orientations of ice masses (in parentheses). $B-B^{\prime}$ is the line of cross-section shown in Figure 5. The contour interval is $50 \mathrm{~m}$.

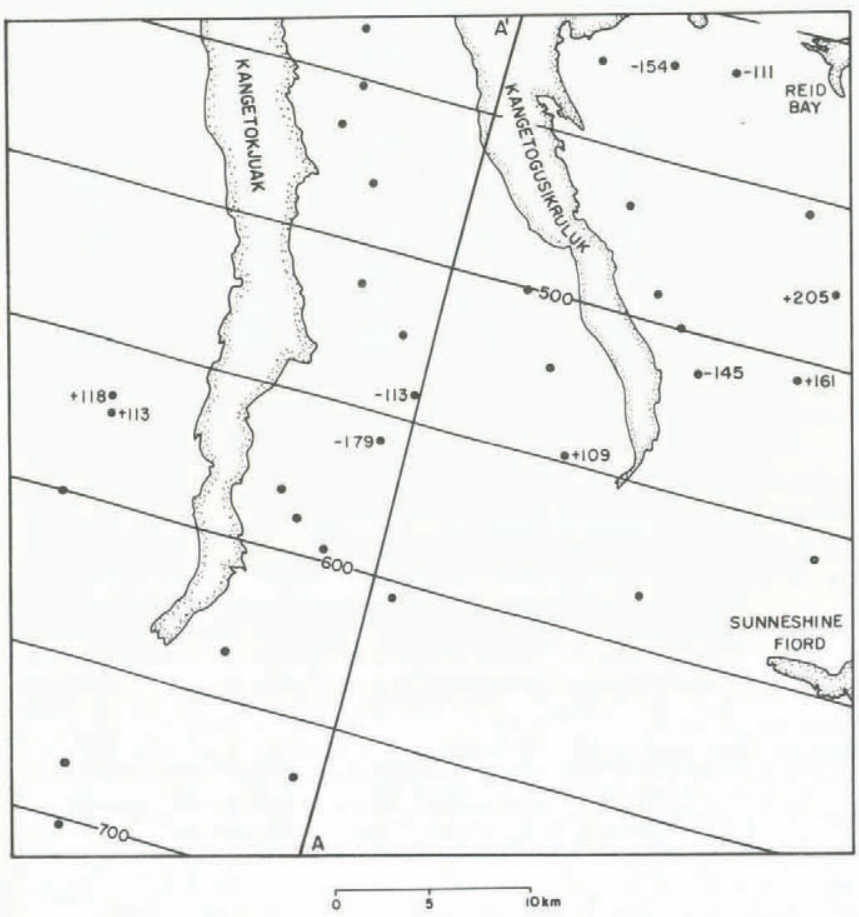

Fig. 4. First-order trend surface of late Foxe ELAs showing the distribution of data points and residuals in excess of $\pm 100 \mathrm{~m}$. $A-A^{\prime}$ is the line of cross-section shown in Figure 5. The contour interval is $50 \mathrm{~m}$.

Strengths of all trends, indicated by the correlation coefficient $(R)$, are quite high, suggesting that trends correspond well to the data. Analysis of variance shows that all trends differ significantly from the random effect, which means that ELAs do, in fact, vary systematically with respect to geographic location. However, the decrease in unexplained variance obtained by fitting higher-degree regressions to the data is only significant in the case of the former (late Foxe) quadratic surface. Therefore, no further analysis was made of quadratic or cubic trends.

Correlation coefficients for trends of former ELAs are in all cases higher than those of corresponding present 
TABLE III. STATISTICAL DATA PERTAINING TO TRENDS OF MERCHANTS BAY ELAS

$\begin{array}{lcccc}\begin{array}{l}\text { Degree of } \\ \text { regression } \\ \text { equation }\end{array} & \begin{array}{c}\text { \% variance } \\ \text { explained } \\ \text { by }\end{array} & \begin{array}{c}\text { Coefficient } \\ \text { of multiple } \\ \text { correlation }\end{array} & \begin{array}{c}\text { Significance } \\ \text { of } \\ \text { regression }\end{array} & \begin{array}{c}\text { Significance } \\ \text { of increasing } \\ \text { order of } \\ \text { regression }\end{array} \\ & R^{2} \times 100 & R & F \text {-test, 5\% significance level }\end{array}$

Present ELAs (42 observations)

\begin{tabular}{|c|c|c|c|c|}
\hline Linear & 27.88 & 0.53 & yes & - \\
\hline Quadratic & 36.71 & 0.61 & yes & no \\
\hline Cubic & 50.26 & 0.71 & yes & no \\
\hline \multicolumn{5}{|c|}{ Paleo-ELAs (34 observations) } \\
\hline Linear & 39.09 & 0.63 & yes & - \\
\hline Quadratic & 63.48 & 0.80 & yes & yes \\
\hline Cubic & 72.93 & 0.85 & yes & no \\
\hline
\end{tabular}

TABLE IV. STATISTICAL DATA PERTAINING TO RESIDUALS IN EXCESS OF $\pm 100 \mathrm{~m}$ FROM THE FIRST-ORDER TREND SURFACES

\begin{tabular}{lccccc} 
& & \multicolumn{2}{c}{ Maximum } & Mean & Std dev. \\
& + & - & $\bar{x}$ & $s$ & $n$ \\
Present & $434 \mathrm{~m}$ & $256 \mathrm{~m}$ & $203 \mathrm{~m}$ & $100 \mathrm{~m}$ & 16 \\
$\begin{array}{l}\text { Paleo } \\
\text { (late Foxe) }\end{array}$ & $205 \mathrm{~m}$ & $179 \mathrm{~m}$ & $137 \mathrm{~m}$ & $58 \mathrm{~m}$ & 10
\end{tabular}

trends. This contrast is also reflected by the greater number and magnitude of residuals in excess of $100 \mathrm{~m}$ from the present linear trend than from the former linear trend (Figs 3 and 4); data relating to residuals from first-order trends are presented in Table IV. Residuals from the former trend are evenly distributed with respect to sign. However, positive deviations from the present trend are fewer, but of greater magnitude than negative deviations. The largest positive residuals from the present trend are located on high mountain massifs, in south-facing valleys. One conclusion that may be drawn is that ELAs, at present, are more affected by local factors (e.g. aspect and topography), whereas paleo-ELAs varied more in a purely regional sense due to orographic and atmospheric effects. This conclusion is supported by the fact that a higher-order surface fitted to the present ELA data does not significantly improve the explanation of variance, whereas the late Foxe quadratic trend does provide a substantially better fit.

Linear trends of present and paleo-ELAs show contrasts with respect to orientation and elevation. The azimuth of the present surface is $147^{\circ}$ with a north-easterly dip; the azimuth of the former trend is $105^{\circ}$ and the dip is north-north-east. The trend of ELAs in the area has shifted $42^{\circ}$ since the late Foxe maximum, from a north-north-easterly to an east-north-easterly aspect. The maximum inclinations of the surfaces differ somewhat (Fig. 5 ), with the present surface having $14 \%$ higher gradient than the former trend.

ELA lowering, as computed from raw data, varies between 55 and $335 \mathrm{~m}(\bar{x}=180 \mathrm{~m}, s=83 \mathrm{~m}, n=23)$. Determinations made using predicted present and former trend values show a similar range - from 67 to $338 \mathrm{~m}(\bar{x}=$ $205 \mathrm{~m}, s=65 \mathrm{~m}, n=95$ ). Figure 6 is a map of ELA depression constructed using trend-lowering data, contoured at a $50 \mathrm{~m}$ interval. It shows greatest amounts of ELA lowering in the north-west corner of the study area, and
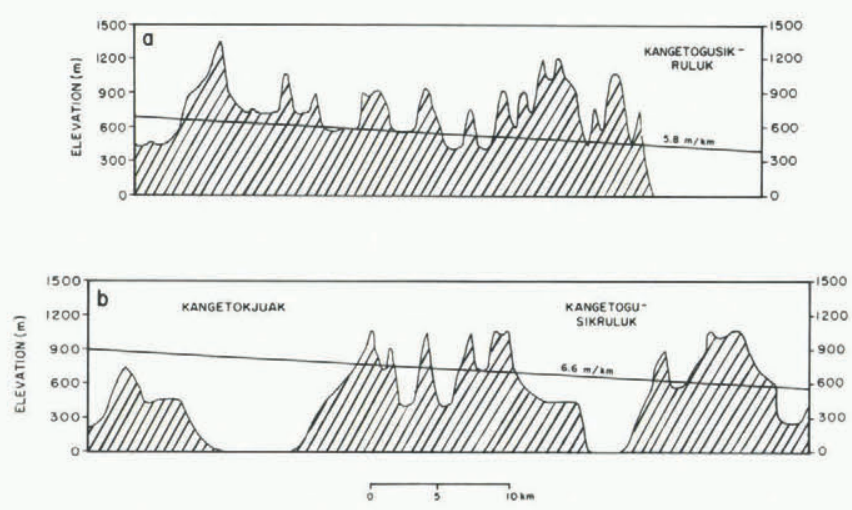

Fig. 5. Topographic profiles and maximum ELA gradients from linear trend surfaces. Locations of sections are shown in Figures 3 and 4. a. Late Foxe ELAs; b. Present ELAs. The vertical exaggeration is $x 8$.

least amounts in the south-east corner of the study area. However, ELA differences computed from actual data show no such systematic variation across the area. This lack of systematic change may be a result of the increased dominance of local climatic, geographic, and topographic influences at present, or of variation in glacier morphology.

\section{Paleoenvironment}

There are several paleoenvironmental implications of changes in the regional trend of ELAs. Change in the orientation of the trend surface may be attributed to shifting of storm tracks from north to south and south-west 


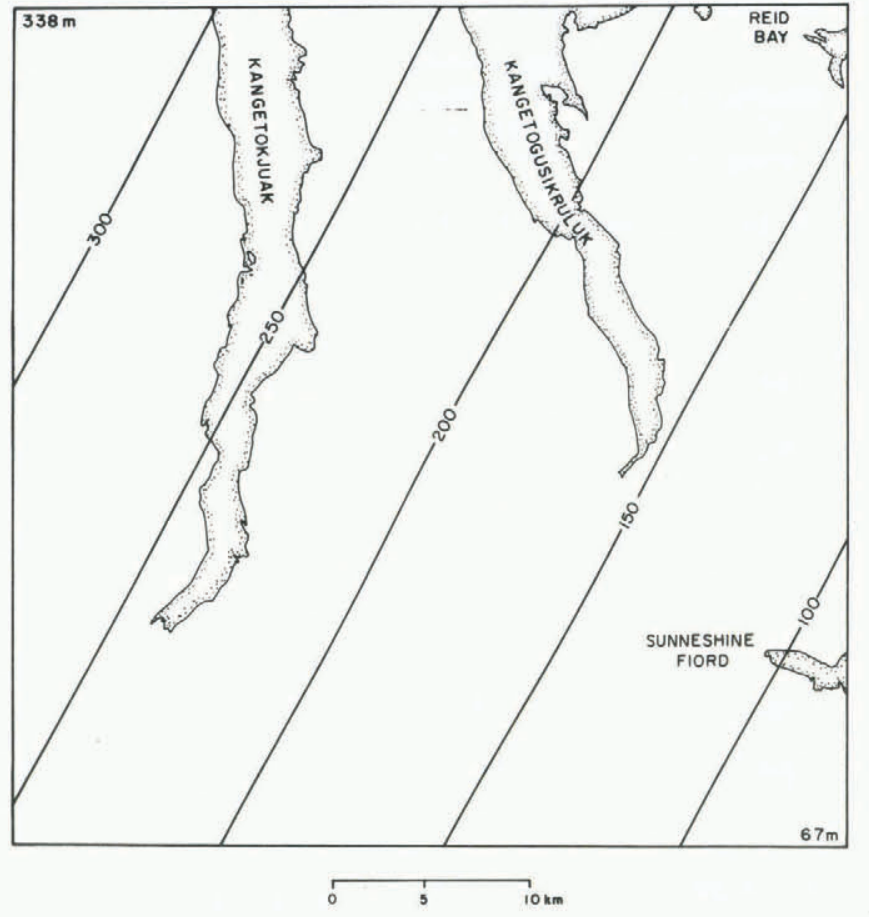

Fig. 6. Map of ELA depression in the Merchants Bay area. Contours are lines of equal difference between first-order trend surfaces of present and late Foxe ELAs. Numbers in the north-east and south-east corners are maximum and minimum differences, respectively. The contour interval is $50 \mathrm{~m}$.

over the last $10 \mathrm{ka}$ (Barry, 1981; Locke, unpublished). A present there is a strong precipitation gradient across the region; the precipitation at Cape Dyer is about four times that at Padloping Island. This is a result of cyclogenesis in the Labrador Sea and storms tracking into Davis Strait from the south and south-west, as well as the presence of a persistent polynya off Cape Dyer. The trend of present ELAs shows strong affinity to this source of moisture, both in azimuth and inclination. The slightly greater dip of the present surface may be related to the proximity of moist maritime conditions. Past workers (Meier and Post, 1962; Andrews and Miller, 1972) have noted the increased slope of regional ELA trends toward the coast and have attributed this to increasing oceanic influence.

In contrast, the late Foxe trend is oriented more nearly normal to the coastline north of Merchants Bay. This fact and the lower slope of the surface indicate more continental conditions and lower temperatures over the region (Locke, unpublished). The greater effective distance from a source of moisture that these conditions imply can be explained by the existence of extensive (possibly perennial) sea ice in Davis Strait adjacent to the Baffin Island coast, and/or by a northerly storm track into Baffin Bay-Davis Strait. Thus, analysis of paleo-ELAs leads to the assertion that the climate in the Merchants Bay area during the late Foxe stade was both colder and dryer than at present. This is consistent with the conclusion of Miller and Williams (1974), who used a computer snow-melt model to determine that summer temperatures in the Merchants Bay area were 2-6 deg lower than at present, and that snowfall was 30\% lower.

\section{DISCUSSION}

There are some apparent methodological similarities betwen this study and the one performed by Meierding (1982). In actuality, the respective statistical approaches differ substantially. Both studies involve statistical comparison of paleo-ELAs of reconstructed late Quaternary mountain glaciers determined by a variety of commonly used methods, and both make use of trend-surface analysis of regional ELA data. Meierding (1982) used trend-surface analysis to facilitate a comparison of different methods of estimating paleo-ELAs. However, in this study trend-surface analysis is used to contrast ELAs of modern and reconstructed glaciers determined by the AAR method. A paired $t$-test is employed to determine whether paleo-ELAs calculated by different methods are comparable.

Meierding's (1982) analysis rests on the assumption that first-order trend surfaces best fit regional ELA data but this premise was not tested. Although some workers have shown this to be the case for their particular study areas, it does not necessarily follow that this should hold true for all areas. Such factors as local and regional climate and physiography, and the distribution of data points within the area sampled, can affect the form and complexity of the regional trend of ELAs. Therefore, it is precarious to conclude that the technique that provides the best fit to some predetermined type of trend surface is the best method of estimating paleo-ELAs. If the regional trend of ELAs is influenced by the unique physical environment in which a sample of glaciers exists, then ELA data should be used to determine the appropriate trend surface to best describe the data, and not the other way around. The objective approach employed in this study is to use analysis of variance both to demonstrate the significance (or lack thereof) of each trend surface, and to determine the appropriate type of surface to be used in subsequent analysis. This approach avoids undue reliance on tenuous assumptions regarding the nature of ELA variation (and, by inference, paleoenvironmental conditions) across a region.

\section{ACKNOWLEDGEMENTS}

This study was conducted as part of the author's M.Sc. thesis and was supported primarily by the U.S. National Science Foundation (grant EAR77-24555) through the University of Colorado, and Drs J.T. Andrews and G.H. Miller. Generous support from the American Alpine Club, Sigma Xi (the Scientific Research Society of North America), and the Department of Geological Sciences, University of Colorado, is gratefully acknowledged.

\section{REFERENCES}

Andrews, J.T. 1965. The corries of the northern Nain-Okak section of Labrador. Geographical Bulletin, Vol. 7, No. 2, p. 129-36.

Andrews, J.T. [ $\left.{ }^{\mathrm{C}} 1975.\right]$ Glacial systems. An approach to glaciers and their environments. North Scituate, MA, Duxbury Press. (Environmental Systems Series.)

Andrews, J.T., and Miller, G.H. 1972. Quaternary history of northern Cumberland Peninsula, Baffin Island, N.W.T. Canada: Part IV: Maps of the present glaciation limits and lowest equilibrium line altitude for north and south Baffin Island. Arctic and Alpine Research, Vol. 4, No. 1, p. 45-59.

Andrews, J.T., and others. 1970. An inventory of the present and past glacierization of Home Bay and Okoa Bay, east Baffin Island, N.W.T., Canada, and some climatic and palaeoclimatic considerations, by J.T. Andrews, R.G. Barry, and L. Drapier. Journal of Glaciology, Vol. 9, No. 57, p. 337-62.

Barry, R.G. 1981. The nature and origin of climatic fluctuations in northeastern North America. Géographie Physique et Quaternaire, Vol. 35, No. 1, p. 41-47.

Bates, R.L., and Jackson, J.A., ed. 1980. Glossary of geology. Second edition. Falls Church, VA, American Geological Institute.

Davis, J.C. 1973. Statistics and data analysis in geology. New York, John Wiley and Sons.

Dugdale, R.E. 1972. A statistical analysis of some measures of the state of a glacier's "health". Journal of Glaciology, Vol. 11, No. 61, p. 73-79.

Flint, R.F. ['1971.] Glacial and Quaternary geology. New York, N.Y., etc., John Wiley and Sons.

Hawkins, F.F. Unpublished. Glacial geology and late Quaternary paleoenvironment in the Merchants Bay area, Baffin Island, N.W.T., Canada. [M.Sc. thesis, University of Colorado, 1980.] 
Krumbein, W.C., and Graybill, F.A. 1965. An introduction to statistical models in geology. New York, N.Y., McGraw-Hill.

Locke, W.W. Unpublished. The Quaternary geology of the Cape Dyer area, southeasternmost Baffin Island, Canada. [Ph.D. thesis, University of Colorado, 1980.]

Manley, G. 1959. The late-glacial climate of north-west England. Liverpool and Manchester Geological Journal, Vol. 2, Pt. 2, p. 188-215.

Meier, M.F. 1962. Proposed definitions for glacier mass budget terms. Journal of Glaciology, Vol. 4, No. 33, p. 252-61.

Meier, M.F., and Post, A.S. 1962. Recent variations in mass net budgets of glaciers in western North America. Union Géodésique et Géophysique Internationale. Association Internationale d'Hydrologie Scientifique. Commission des Neiges et des Glaces. Colloque d'Obergurgl, 10-9 - 18-9 1962 , p. 63-77. (Publication No. 58 de l'Association Internationale d'Hydrologie Scientifique.)

Meierding, T.C. 1982. Late Pleistocene glacial equilibrium-line altitudes in the Colorado Front Range: a comparison of methods. Quaternary Research, Vol. 18, No. 3 , p. $289-310$

Miller, G.H. Unpublished. Glacial and climatic history of northern Cumberland Peninsula, Baffin Island, Canada, during the last 10,000 years. [Ph.D. thesis, University of Colorado, 1975.]

Miller, G.H., and Williams, L.D. 1974. Late Wisconsin paleoclimate derived from a snowmelt program and variations in glacier response, eastern Baffin Island. Geological Society of America. Abstracts with Programs, Vol. 6, No. 7, p. 870 .

Østrem, G. 1966. The height of the glaciation limit in southern British Columbia and Alberta. Geografiska Annaler, Vol. 48A, No. 3, p. 126-38.
Peterson, J.A., and Robinson, G. 1969. Trend surface mapping of cirque floor levels. Nature, Vol. 222, No. 5188 , p. $75-76$.

Pierce, K.L. 1979. History and dynamics of glaciation in the northern Yellowstone National Park area. U.S. Geological Survey. Professional Paper 729-F.

Porter, S.C. 1964. Composite Pleistocene snow line of Olympic Mountains and Cascade Range, Washington. Geological Society of America. Bulletin, Vol. 75, No. 5, p. 477-82.

Porter, S.C. 1968. Determination of equilibrium-line altitudes for late Quaternary alpine glaciers. Geological Society of America. Special Paper, No. 121, Abstracts for 1968, p. 242.

Porter, S.C. 1970. Quaternary glacial record in Swat Kohistan, West Pakistan. Geological Society of America. Bulletin, Vol. 81, No. 5, p. 1421-46.

Porter, S.C. 1975. Equilibrium-line altitudes of late Quaternary glaciers in the Southern Alps, New Zealand. Quaternary Research, Vol. 5, No. 1, p. 27-47.

Richmond, G.M. 1965. Glaciation of the Rocky Mountains. (In Wright, H.E., jr., and Frey, D.G., ed. The Quaternary of the United States. Princeton, NJ, Princeton University Press, p. 217-30.)

Sissons, J.B., and Sutherland, D.G. 1976. Climate inferences from former glaciers in the south-east Grampian Highlands, Scotland. Journal of Glaciology, Vol. 17, No. 76 , p. $325-46$

Williams, L.D. Unpublished. Some factors influencing cirque glacierization on eastern Cumberland Peninsula, Baffin Island, Canada. [M.Sc. thesis, University of Colorado, 1972.]

Williams, V.S. 1983. Present and former equilibrium-line altitudes near Mount Everest, Nepal and Tibet. Arctic and Alpine Research, Vol. 15, No. 2, p. 201-11. 